\title{
Non-native EFL Teacher Trainees' Attitude towards the Recruitment of NESTs and Teacher Collaboration in Language Classrooms
}

\author{
Li-Yi Wang \\ Office of Education Research, National Institute of Education, Singapore
}

\begin{abstract}
Teacher collaboration is a key feature of effective professional development and is a necessary element for improved student achievement and ongoing school success. This study investigated pre-service Non-Native English Speaking Teachers (NNESTs)' attitude towards the recruitment of Native English Speaking Teachers (NESTs) and the collaboration with NESTs in EFL classrooms. The results show that most participants are not against the presence of NESTs as their teaching partners, but see qualification as the key criterion in recruiting NESTs. Even though the participants believe that team teaching with NESTs is beneficial to English learners, they are concerned about unequal partnerships and communication problems with NESTs. The results suggest that teacher educators need to take greater responsibilities to engage preservice teachers in team teaching to support pre-service teachers' professional lives.
\end{abstract}

Index Terms - teacher collaboration, team teaching, professional development, English teacher education

\section{INTRODUCTION}

Teachers' attitude is an important concept in understanding teachers' thought processes, foreseeing teachers' classroom practices, and planning teacher education programs (Richardson, 1996). It also strongly determines the way teachers teach, the way they develop as teachers and their reaction to educational changes (Beijaard et al., 2004). In particular, for pre-service teachers, initial teacher training is an important time for them to begin to construct a teacher image and identity that would support and sustain them in their future profession (Timostsuk \& Ugaste, 2010). Focusing on pre-service NNESTs' attitude toward team teaching with NESTs, this study investigated pre-service NNESTs' (1) response to the government's NESTs-hiring policy, (2) belief about the benefits of team teaching with NESTs, and (3) concerns about team teaching with NESTs. The findings to the proposed questions should provide a better understanding about pre-service NNESTs' attitude towards collaboration with NESTs. Since teacher collaboration plays a significant role in teacher professional development, student achievement and school success, the paper will be of particular interest to English teacher educators and policymakers in countries where NESTs-NNESTs team teaching is implemented.

\section{LITERATURE REVIEW}

In the past decade, researchers have reviewed professional development for teachers and reported consensus in their summary of key features for effective professional development (Crawford et al., 2008; Desimone, 2009; Wayne et al., 2008). These key features include: content focus, coherence, duration, active learning, and collective participation. Professional development that is ongoing, subject-specific, and collaborative allows teachers to practice their new skills and provide a mechanism to debrief and gather new information (Dove \& Honigsfeld, 2010; Servage, 2008). Collaborative practice is regarded as central to professional development because teachers learn most effectively when learning is collaborative and collegial (Darling-Hammond \& Richardson, 2009). Teacher collaboration is a "powerful format of teacher learning" (Desimone, 2009, p.184). It provides further opportunities for teachers to establish networks of relationships through which they may reflectively share their practices, revisit beliefs on teaching and learning and co-construct knowledge (Achinstein, 2002; Chan \& Pang, 2006; Clement \& Vandenberghe, 2000). Teacher collaboration is thus regarded as a necessary element for effective teaching practice, improved student achievement and ongoing school success (DelliCarpini, 2008; Guiney, 2001).

Since teacher collaboration is regarded as necessary for teacher learning and student achievement, an important matter to consider is how collaborative efforts are presented and implemented. Historically, collaborative approaches are presented through co-teaching. Cook and Friend (1995) define co-teaching as having four components, including two educators working together, instruction delivery by both teachers, a heterogeneous group of students, and a single classroom. These components are incorporated into several co-teaching models that have been developed, including team teaching (Hang \& Rabren, 2009). Team teaching can be described as a practice in which two or more teachers cooperatively plan, instruct, and evaluate one or more groups in an appropriate instructional space and given length of time, so as to take advantage of the unique competencies of the team members (Buckley, 2000; Friend \& Cook, 2010). 
As representative forms of collaborative approaches, co-teaching and team teaching are akin to natural allies, providing support to teachers and students.

Research on teacher collaboration in English Language Teaching (ELT) has been carried out in international contexts (e.g., Arkoudis, 2003, 2006; Creese, 2005, 2006; Davison, 2006; Gardner, 2006; York-Barr et al., 2007), and one central argument in the discussion of teacher collaboration in ELT is the belief that the collaboration between native English speaking teachers (NESTs) and non-native English speaking teachers (NNESTs) might make a unique contribution to English language education. This belief has been shown in a number of projects carried out around the world, in particular in some well-known programs in certain relatively wealthy Asian Pacific countries, such as the JET Program (Japan Exchange and Teaching Program) in Japan, the EPIK (English Program in Korea) in Korea, the NET Scheme (Native-speaking English Teacher Scheme) in Hong Kong (China), and the FETRP (Foreign English Teachers Recruitment Program) in Taiwan. These programs have become part of the central governments' language education policies in these countries. The majority of the NESTs recruited via these programs are expected to conduct team teaching with local English teachers at public primary and secondary schools.

In the NESTs-NNESTs context, the idea that a NEST and a NNEST should work together by building on each other's strengths is based on the assumption that some roles may be better taken on by the NEST rather than the NNEST, and vice versa (Tajino \& Tajino, 2000). Given that an ideal English language teaching environment is one in which NESTs and NNESTs can complement each other in maximizing their strengths and minimizing their weaknesses, it seems that the concept of team teaching can successfully build an ideal ELT environment for learners (Medgyes, 1992). Nevertheless, regardless of the benefits team teaching can bring to English learners and local NNESTs (e.g., Buckley, 2000; Carless, 2002, 2006; Carless \& Walker, 2006), literature looking into the administration of NESTsNNESTs team teaching suggest that this collaborative teaching model has significant impact on local NNESTs. First of all, the presence of NESTs is often perceived as a threat by local English teachers, which eventually results in an unwelcoming atmosphere among non-native English teachers towards the government-hired NESTs (Boyle, 1997; Lung, 1999; Niederhauser, 1995). In addition, team teaching with NESTs often makes local English teachers doubt their own English competence. Many local non-native English teachers are reluctant to engage in team teaching with NESTs because they feel uneasy about their competence in English (Browne \& Wada, 1998; Carless, 2004; Reiko \& Lee, 2001) Furthermore, team teaching creates an imbalance of power in the relationship between NESTs and local English teachers (Carless, 2002; Fujimoto-Adamson, 2010; Kumabe, 1996; Mahoney, 2004; McConnell, 2000). Lastly, the administration of team teaching often puts local English teachers through a series of struggle about conflicting teaching objectives (Carless, 2004, 2006).

NESTs-NNESTs team teaching has drawn extensive discussion. However, nearly all of the studies focused on inservice NNESTs. There is little understanding about pre-service NNESTs' attitude towards collaborating with NESTs. To find out how pre-service NNESTs' view their professional roles and revamp teacher training education, there is a need to understand these teachers' attitude towards collaborating with NESTs. In addition, most studies were conducted in the JET Program, the EPIK and the NET Scheme contexts, three relatively larger, well-documented and longstanding programs. To present a panoramic picture of NESTs-NNESTs team teaching in ELT classrooms, this study targeted the FETRP, a smaller and more recent NESTs-hiring program launched by the Taiwanese government less than a decade ago.

\section{METHODOLOGY}

\section{A. Participants}

The participants of this study were recruited from the English language departments at 2 normal universities and 3 universities of education located in northern, central, and eastern Taiwan in the spring and summer of 2007. Since these universities are the major sources of public primary and secondary English teachers in Taiwan, students enrolled in these universities are committed and expected to become prospective elementary and secondary school English teachers in Taiwan. All the participating universities had NESTs as teaching staff at the time this study was conducted. In Taiwan, the frequency and accessibility of contact with NESTs vary significantly, greatly depending on the areas in which the institutions are located. In addition, the entrance requirements of and the courses offered by the English departments in different normal universities and universities of education vary from one to another. Choosing participants from different institutions located in different areas instead of single, specific university might help reduce any effect caused by geography and premises. The participants were selected according to three criteria. First, the participants must be Taiwanese English teacher trainees who are enrolled in the English departments of normal universities or universities of education in Taiwan. Second, the participants must have completed at least two years of their training programs because students who have undergone at least two years training programs should be more suitable to provide the information this study is targeting as compared to pre-service teachers who have just began the training program. Third, the participants must have had the experience of being taught by NESTs in their history of learning English so that they can understand and respond to the NEST-NNESTs issues concerned in this study.

Out of 270 copies of the closed-ended questionnaire distributed in the first phase of data collection, 260 surveys were returned, yielding a response rate of $96.3 \%$. The high return rate is a strong indication that the sample represents the target community. Of the 260 questionnaires, 2 were deemed invalid due to the failure of completing a half of the 
questions applied to the questionnaire. Out of the final 258 respondents, $128(49.6 \%)$ of the respondents are pre-service secondary English teachers, and 130 (50.4\%) are pre-service elementary English teachers. The even distribution in the number of the respondents preparing to become secondary and elementary English teachers provides a balance of perspectives held by these two groups of pre-service teachers. In line with the demography of pre-service English teachers in Taiwan, of which about $90 \%$ of the student teachers are female, $219(84.9 \%)$ of the respondents in this study are female and $39(15.1 \%)$ are male. At the end of the questionnaire, there is a question seeking the participants' willingness to take part in a subsequent interview. Participants who showed interest in taking part in the interview were asked to leave their names and contact number and/or email address on the questionnaire. Participants who completed the questionnaires and agreed to contribute further data were considered as potential interview participants for data collection in the second phase. In order to reduce any effects resulting from geography, the author eventually recruited 35 pre-service English teachers as interview participants, including 9 male and 26 female from 5 different universities located in 4 different counties in Taiwan.

\section{B. Data Collection and Analysis}

Data collection was divided into two phases. In the first phase of data collection where the close-ended questionnaire is used, four documents including: (1) an inquiry letter (written in English) addressing the purpose of conducting this study; (2) a plain language statement (written in both English and Mandarin); (3) a copy of the questionnaire and interview questions (written in English); and (4) an institutional consent form (written in English) were first sent to the authorities of the concerned departments of the institutions to seek permission to conduct this study. At the meetings with the students, the author gave an oral introduction of the purpose of this study, distributed the consent forms to the students, and answered the queries raised by the students. The participating students were asked to fill out and return the questionnaires on the spot. In the second phase, individual interviews were used to collect data from the participants. The arrangement of the interviews, such as time, location and methods, was mutually discussed and agreed upon by the author and interview participants. More than two-thirds of the interviews were conducted in a face-to-face setting using the seminar rooms in the departments to which the students belonged. Others were conducted through telephone mainly because the participants thought it was more convenient for them. All the interviews were conducted in Mandarin on the assumption that the participants would be able to express their feelings and perspectives more clearly through the use of their mother tongue. All the interviews were audio-taped for transcription purposes. For data processing and analysis, a codebook was assembled to carry out the data coding of the completed questionnaires for computer analysis, including the coding frames (e.g., question items and their responding values and labels) and coding instructions regarding valid and missing data. Statistical analyses such as calculating the means and standard deviations were conducted. As to the qualitative data, since the interviews were conducted in Mandarin and audio-recorded, the content of the interviews were transcribed by the author in Mandarin first. Then the transcription was analyzed using the NVivo 7 computer program. The author first established the major themes according to the topics of the interviews. After that, the author identified the relevant content in the transcription and categorized them into these themes. Information regarding the issues of this study were identified and translated into English for the purpose of reporting.

\section{FINDINGS}

\section{A. Response to the NESTs-hiring Policy}

Regarding the government's NESTs-hiring policy, most participants are not against the recruitment, but see qualification as the key criterion in recruiting NESTs. The vast majority (88.0\%) of the participants either disagreed or strongly disagreed with the idea that the Taiwanese government should hire NESTs to teach English at schools even if they have no teaching certificates, while only $5.4 \%$ either agreed or strongly agreed (Item 1, Table 1). In the interviews, many participants talked about qualification as the prerequisite in the NESTs recruitment policy from the perspective of fairness (Theme 1, Table 2). Edward and Fiona, for example, argue that the NESTs they may engage in team teaching with must be qualified teachers because local Taiwanese English teachers are qualified English teachers. The criteria used to recruit local English teachers must be applied to the recruitment of NESTs:

Edward: The NEST with whom I team teaching must be a qualified teacher. It is unfair if I am a qualified teacher and the NEST is an unqualified teacher...We [Taiwanese English teacher trainees] now have to be certificated teachers in order to become public school teachers. Nowadays the certificate is a piece of evidence proving you are a good teacher, and the same criterion should be applied to those NESTs.

Fiona: I think it is very important that the NEST I might cooperate with is a qualified teacher. We [Taiwanese English teacher trainees] ourselves are qualified teachers. It doesn't make sense to allow NESTs who have not teaching certificates to come to Taiwan and teach with us just because they can speak English.

Some other participants see NESTs' qualification as necessary because they think unqualified NESTs will not benefit students (Theme 2, Table 2). They believe that team teaching with qualified NESTs would not only save them considerable time in communicating with NESTs, but also improve the result of team teaching. The following quotes are representative of this perspective:

Wendy: I think there might be many communication problems between NESTs and me if they are uncertified teachers or have no idea about English teaching. They might not know anything about this field and might plan the 
classes carelessly. If we can't communicate effectively or cooperate well, students might feel confused and don't know where to follow.

Kate: I would care whether the NEST I cooperate with is a qualified teacher or not. I might have to spend a lot of time on communicating with the NEST if he/she is an unqualified teacher. If the NEST is qualified, I might not have to spend that much time on communication, and the quality of communication would be better. A qualified NEST definitely knows how to teach, and I also know how to teach. It would be beneficial to students if we can combine what the NEST learns in his/her home country and what I learn in Taiwan, and apply it to the team teaching class.

\section{B. Belief about the Benefits of Team Teaching with NESTs}

The survey shows that the majority of the participants (73.6\%) believe that it is beneficial to English learners if Taiwanese English teachers teach English together with NESTs in the classrooms, while 10.1\% against the benefits of team teaching on students' learning (Item 2, Table 1). In discussing the benefits of team teaching with NESTs, Dorothy mentioned that 'I think team teaching is beneficial to students. NESTs can complement our [Taiwanese English teachers'] weaknesses and we can complement theirs'. Another participant Andy also said that 'NESTs and Taiwanese English teachers have their respective advantages and disadvantages. They can complement each other, which is a good thing to students'. The perspective is shared by a great number of participants (Theme 3, Table 2). Some participants further pointed out that the most significant advantage that NESTs could bring to the team teaching classes is their strength in phonology:

Bruce: I think it is definitely beneficial to students if Taiwanese English teachers teach English together with NESTs. After all, our [Taiwanese English teachers'] accent is different from that of NESTs. So I think it would be a good idea to have NESTs.

Christine: I think it [team teaching with NESTs] is beneficial to students. I personally think it is not easy for Taiwanese people to learn a foreign language. After all, English is their [NESTs'] mother tongue, not ours. Students would find there are so many things they can learn if they have a chance to see how NESTs pronounce or how NESTs use specific words.

In addition to the respective strength that both kinds of teachers can offer to students, a number of the participants are interested in the atmosphere and environment that team teaching creates for students and the new learning experience team teaching brings to students (Theme 4, Table 2). Petty mentioned that 'I think it's beneficial to students because we [Taiwanese English teachers and NESTs] will create an English environment. The environment will encourage students to express themselves in English. And I think that's pretty helpful to them'. Many participants are also convinced that the presence of NESTs together with Taiwanese English teachers can bring students a 'whole-new' learning experience:

Kevin: The model [team teaching] is new to students and can motivate students to learn the language. They will find learning English is not only for exams but also for communication. In the short term, learning English is for exams. But in the long term, the purpose of learning English is to communicate with foreigners. Team teaching is a great help to students. English classes are no longer just exams, exams, and exams.

Helen: I think team teaching provides students with different learning experience. Two teachers working together can definitely offer students something exciting and special. Students may thus learn something different.

In addition to the benefits of team teaching to students' learning, many participants believe that team teaching with NESTs is beneficial to their professional development (Theme 5, Table 2). As English teachers, they believe that they can get more chances to improve their teaching by team teaching with NESTs:

Laura: I can fix up my weakness in teaching skills by watching the way NESTs teach. I can also improve my English proficiency by communicating with NESTs. And NESTs may learn grammar concepts which confuse them from me. I think this [team teaching with NESTs] is pretty good.

Christine: I would like to take a look at their [NESTs'] teaching methods and compare that with ours [Taiwanese English teachers' teaching methods]. I feel that their teaching methods are much open and flexible than ours. They normally allow students to learn or develop freely but propose questions whenever it is suitable. I would like to see how they manage classrooms and conduct teaching activities.

The participants' belief that team teaching with NESTs is beneficial to students' learning and their professional development also reflects on their willingness to carry out team teaching with NESTs. Less than half (49.3\%) of the participants claimed that they looked forward to team teaching with Taiwanese English teachers (Item 3, Table 1). In contrast, as many as $63.6 \%$ of the participants either agreed or strongly agreed that they looked forward to team teaching with NESTs (Item 4, Table 1). The results suggest that the participants are more interested in team teaching when the teaching partners are NESTs rather than Taiwanese English teachers.

\section{Concerns about Team Teaching with NESTs}

In the interview, participants discussed their concerns about team teaching with NESTs, among which the most frequently mentioned concern is NESTs' dominance and NNESTs' marginalization in the classrooms (Theme 6, Table 2). Based on their observation or experience, a number of participants are afraid that in team taught classes, NESTs might take over the whole class and they might become teaching assistants, living translators, or servants who are only responsible for preparing teaching materials or running errands without actually being involved in the teaching of English. The following quotes are representative of this concern among the participants: 
Harry: I have heard quite often that when NESTs who are hired by the government teach in the classrooms, they usually play the role of dominant teacher and become the only authority in the classrooms. It becomes very difficult to allocate the time and duty. To local Taiwanese teachers, they feel like their classes are taken over by the NESTs.

Emily: I have experience of observing a team teaching class and it was like the Taiwanese teacher was just a translator and the NEST dominated the class. The Taiwanese teacher just followed what the NEST said and assisted the NEST aside. The feeling is that the Taiwanese teacher was just a translator and there's actually no team teaching.

Laura: When NESTs teach in the classrooms, they show little respect to Taiwanese teachers who are allocated to team teaching with them. They even see Taiwanese teachers as teaching assistants and ask them to prepare teaching materials or run some errands. Team teaching is actually a lie because Taiwanese teachers seldom have chance to talk when NESTs teach on the platform. Basically, it is NESTs who dominate the classes. Taiwanese teachers are like assistants or servants.

Another major concern the participants had about team teaching with NESTs is communication problems with NESTs (Theme 7, Table 2). Many participants see the quality of communication with NESTs as a crucial factor in determining whether team teaching can be carried out successfully. Edward and Bruce, for example, believe that the success of team teaching depends on whether the two teachers can communicate effectively:

Edward: Communication before conducting team teaching is very important. I think it is necessary for two teachers to communicate well regarding the purpose of the lesson, the essence of teaching and the distribution of duties in advance if team teaching is applied.

Bruce: I think we [the NEST and I] might need to communicate a lot before we cooperate. It may become a big problem if we cannot get along with each other well. In that case, it would be really difficult to carry out team teaching. It is very important to cultivate our unspoken consensus beforehand.

To a number of participants, establishing effective communication with NESTs is not an easy job even though they are aware of its importance. They are worried about the conflicts and tensions which may result from their communication with NESTs because of the different personalities, different beliefs about teaching English, different cultural backgrounds and different professional training between NESTs and themselves. The following quotes are representative of their concern:

Jams: I feel that foreigners are quite stubborn. It seems that it's hard to persuade them to change their thought. I am quite worried about this. They might be very straight to me if they don't like my lesson plans. They might not change their feeling or opinion regarding my lesson plans.

Vera: I think more or less there would be communication problems. After all, we [The NEST and I] have different culture. The professional training we have taken might also be different from each other. It's possible that we have different opinion about teaching methods.

The participants' concerns about team teaching with NESTs also reflect their attitude towards conducting English classes without the presence of NESTs. As many as $44.9 \%$ of the participants either agreed or strongly agreed that they would prefer teaching English alone if they could choose, while 16.6\% either disagreed or strongly disagreed (Item 5, Table 1). This finding suggests that given the choice of conducting English classes alone, nearly half of the participants would opt for individual teaching rather than team teaching with NESTs. With regard to this survey result, the interviews provide more detailed information. Many participants mentioned that they would prefer teaching alone even though they thought team teaching was also beneficial to students' learning. They opted for individual teaching simply because they thought that individual teaching would be a more 'effective' way of teaching English (Theme 8, Table 2):

Daniel: There are a lot of things need to be taken into account in team teaching, including the distribution of the duty and the timing of exchanging leading role and supporting role played respectively by the two teachers. It is hard to control the timing and tempo. I prefer teaching alone because I think it is more effective. Team teaching involves more jobs and takes more time to prepare the classes. I think it is a bit troublesome.

Theresa: Once upon a time we [Taiwanese English teacher trainees] went observing English teaching at a school. There were a NEST and a Taiwanese teacher team teaching together. I found that the NEST couldn't discover the students' confusion in the class. The teaching practice was actually dependent on the Taiwanese teachers' coordination...I was wondering why it took two English teachers to accomplish the class that actually could have been done by just one single Taiwanese teacher.

\section{DISCUSSION}

NNESTs can benefit professionally from collaboration with NESTs (Carless \& Walker, 2006). Moreover, English learners and teachers themselves can benefit more from team teaching classes if team teaching participants are welltrained ELT practitioners (Carless, 2006). In this study most participants are not against the policy of recruiting qualified NESTs and show a great extent of interest and willingness to engage in team teaching with NESTs. These findings reveal the participants' positive attitude towards collaborating with NESTs as "the other kind" of English teachers in the classrooms, contrary to findings in previous studies. The participants' extended contact with NESTs in universities and their personal experience in learning English with NESTs could have helped the participants to develop a positive attitude towards team teaching with NESTs. However, although the concept of team teaching is some 40 years old, many still consider it a "new" methodology, and a fairly "threatening" one at that (Marilyn, 2010). In team 
taught classes, giving up control of what used to be a solo classroom venture requires mutual trust between team teachers. In this study, team teaching with NESTs seems to be a threatening approach to the participants because it marginalizes their professional roles in the classrooms. Similar concern among NNESTs has been reported in the literature. Being affected by the influential ideology of Confucianism, a typical classroom practice in many countries in Asia is teacher-centered with students acting as obedient and silent recipients. Teachers normally perceive themselves as the only source of knowledge and authority in the classrooms. This might explain the participant's concerns regarding losing their authority to NESTs in team taught classes.

The success of team teaching is largely depends on the effectiveness of communication between team teachers. To a great number of participants, the conflicts and tensions which result from the communication process with NESTs seem to be inevitable due to the difference in personalities, cultural background and professional training between NESTs and themselves. Similar concerns have also been reported in the literature. Arguably, in countries where high-stakes tests are widely used, traditional English teaching practices feature intensive drillings and learning by rote. Communicative English teaching carried out by NESTs in team taught classes is often in conflict with grammar and reading-based preparation for examinations. This might explain why nearly half of the participants would prefer teaching alone if they could choose. This finding corresponds to the findings in the literature, with the observation that many NNESTs either conduct all or none of their supposedly team taught lessons. For English teachers in many EFL or educational contexts, they tend to work largely in isolation (Lee, 2011). The notion of team teaching is sometimes perceived as a foreign product by NNESTs, who believe that "there should be one chef in the kitchen, one authority" (Carless, 2004, p.10). This deeply-rooted educational philosophy might contribute to the participants' hesitation towards collaborative teaching.

The findings of this study have several implications on teacher education and teacher educators. First, a shift in the conception of preparing teachers from individual and isolated way to collaborative and collective model is needed. Teacher education is all about modeling (McHatton \& Daniel, 2008). Since teacher collaboration departs significantly from the traditional "one teacher per classroom" model, it is not reasonable to expect teachers to understand and implement it without specific instruction in the pertinent knowledge and skills (Friend et al., 2010). Teacher educators are prompted to think more holistically and attend not only to the development of instructional competence but to professional dispositions and skills for collaborating with others in instructional planning and assessment and the actual implementation of various co-teaching approaches. This can be done by first providing teachers with in-depth training in collaborative teaching at the pre-service level (Cramer et al., 2010; Cochran-Smith, 2004; Darling-Hammond, 2006; LeCornu, 2005). For example, Gaytan (2010) provides the theoretical framework for team teaching and a description of instructional strategies to accommodate a team teaching approach. These strategies include joint engagement in progressive and extensive planning of all aspects of the course, joint attendance and teaching in all class meetings, and debate-infused teaching. These strategies are necessary for instructors to successfully adjust their teaching methods for team teaching. Training courses focusing on the discussion of these aspects could enhance pre-service teachers' understanding about the complexity and application of such a concept.

Second, team teaching is based on the idea that a team of instructors is collectively planning and executing classroom instruction (Booth et al., 2003). A fundamental requirement of team teaching is to have a direction for the course (Conn, 2010, p.88). However, it takes time for team partners to share the missions and understand the goals, and it is expected to see varying levels of resistance from team members. Collaborative skills such as collegial enquiry and reflection are needed to resolve conflicts (Clouder et al., 2006; Pedder \& MacBeath, 2008), and engaging in collaborative learning seems to be a promising way to develop these collaborative skills (Chai \& Tan, 2009; Laurillard, 2009). Team teaching may be most effective when it is "team learning" (Tajino \& Tajino, 2000), in which team teachers are encouraged to engage jointly in information exchange, consultation, and transfer of responsibilities. In her review on collaborative learning, Cohen (1994) concluded that complex, ill-structured and open-ended learning tasks stimulate collaboration between learners. These kinds of tasks allow learners to suggest multiple solutions in different ways because they often require learners to make judgments and express personal beliefs and opinions, stimulating both reflection and discussions (Goel, 1992; Jonassen, 2000). On the contrary, there are researchers who argue that learning tasks which allow a high level of learner participation, interaction, communication and collaboration require a certain level of structure. The more the goals, milestones, and roles that are set out, the more learners will participate in discussions and collaborative work (Dillenbourg, 2002; Lockhorst et al., 2010). Engaging in these kinds of tasks, whether ill-structured or well-structured ones, would allow team teachers to surface some of their greatest challenges, creating networks of support for problematic situations in their team teaching partnerships, which helps team teachers to reach dynamic levels of collaboration (Pawan \& Ortloff, 2011). Teacher training programs at pre-service level can use these tasks as access points to support teacher collaboration.

Lastly, it is important that while pre-service teachers begin to develop a conceptual understanding of team teaching, they need to have opportunities to experience how team teaching actually work during this critical time. It is noted that paired field placements can lead to increased dialogue about teaching and learning and have the potential to help preservice teachers nurture and develop skills of collaboration (Gardiner \& Robinson, 2009). Training programs should provide pre-service teachers with such kind of opportunities to practice team teaching in real classroom settings through 
partnerships between teacher training institutes and schools in order to help pre-service teachers engage in collaborative approaches and explore how team teaching can best serve pedagogy.

This study provides preliminary information regarding pre-service NNESTs' attitude towards collaborating with NESTs. However, NEST-NNEST team teaching is a highly challenging approach to teaching which involves complex issues in its application in classrooms. The questions used in the survey appear to be simplistic or terse. The findings of this study have brought to light a number of issues that future research could investigate. One issue that could be followed up on is the comparison of the results gained from in-service English teachers and pre-service English teachers. Any difference that is to be found in the group of practicing teachers will point to the need for studies on the nature of this change and its reasons. Also, an investigation of how team teaching actually works in the classroom through classroom observation would provide a closer look at the impact of this collaborative teaching model on NESTs' and NNESTs' teaching practices.

\section{CONCLUSION}

Involvement in professional development through teacher collaboration provides opportunities to develop teacher leadership, enhance student learning, and promote school success (Borko, 2004; Dove \& Honigsfeld, 2010). In light of the continued emphasis on teacher development through collaborative approaches and processes, it is crucial for policy makers, school administrators, teacher educators, and teachers themselves to work together to promote sustainable efforts to support teacher collaboration. This study investigated pre-service NNESTs' attitude towards the recruitment of NESTs and teacher collaboration in the classrooms. The results show that the participants are not against the policy of recruiting NESTs and are willing to engage in team teaching with NESTs. However, team teaching with NESTs seems to be threatening to the participants because it marginalizes their professional roles. Given the complexity of collaborative approaches to teaching, pre-service teachers need to gain a greater understanding of how to collaborate effectively with NESTs as equal partners. Engaging teachers in collaboration at the pre-service level may yield improved results when these teachers eventually take part in collaborative teaching at the in-service level (McHatton \& Daniel, 2008). The exposure to a collaborative approach at the pre-service level would provide an opportunity to address misconceptions about students with differing academic abilities and needs, and allow for structured experiences with corresponding debriefing sessions. It would also help to address the roles and responsibilities of team teachers working together to ensure academic success for learners. Producing teachers who are competent and confident in their capability to operate in a collaborative setting will have a positive impact on teachers' professional development and students' learning. It is incumbent upon teacher educators to equip pre-service teachers with the methods and procedures involved in collaborative approaches in order to support teachers' professional lives.

\section{APPENDIX}

TABLE 1:

RESPONSE TO THE SURVEY QUESTIONS

\begin{tabular}{|c|c|c|c|c|c|c|c|}
\hline \multicolumn{2}{|c|}{ Question item } & SD & $\mathrm{D}$ & $\mathrm{N}$ & $\mathrm{A}$ & SA & Mean\# (SD) \\
\hline 1 & $\begin{array}{l}\text { The Taiwanese government should hire NESTs even } \\
\text { though they have no teaching certificates }\end{array}$ & $\begin{array}{l}131 \\
(50.8 \%)\end{array}$ & $\begin{array}{l}96 \\
(37.2 \%)\end{array}$ & $\begin{array}{l}17 \\
(6.6 \%)\end{array}$ & $\begin{array}{l}11 \\
(4.3 \%)\end{array}$ & $\begin{array}{l}3 \\
(1.1 \%)\end{array}$ & $\begin{array}{l}1.68 \\
(0.86)\end{array}$ \\
\hline 2 & $\begin{array}{l}\text { It is beneficial to English learners if Taiwanese } \\
\text { English teachers teach English together with NESTs }\end{array}$ & $\begin{array}{l}1 \\
(0.4 \%)\end{array}$ & $\begin{array}{l}25 \\
(9.7 \%)\end{array}$ & $\begin{array}{l}42 \\
(16.3 \%)\end{array}$ & $\begin{array}{l}137 \\
(53.1 \%)\end{array}$ & $\begin{array}{l}53 \\
(20.5 \%)\end{array}$ & $\begin{array}{l}3.84 \\
(0.88) \\
\end{array}$ \\
\hline 3 & $\begin{array}{l}\text { I look forward to team teaching with Taiwanese } \\
\text { English teachers }\end{array}$ & $\begin{array}{l}5 \\
(1.9 \%)\end{array}$ & $\begin{array}{l}40 \\
(15.5 \%)\end{array}$ & $\begin{array}{l}86 \\
(33.3 \%)\end{array}$ & $\begin{array}{l}109 \\
(42.2 \%)\end{array}$ & $\begin{array}{l}18 \\
(7.1 \%)\end{array}$ & $\begin{array}{l}3.37 \\
(0.90)\end{array}$ \\
\hline 4 & I look forward to team teaching with NESTs & $\begin{array}{l}4 \\
(1.5 \%)\end{array}$ & $\begin{array}{l}20 \\
(7.8 \%)\end{array}$ & $\begin{array}{l}70 \\
(27.1 \%)\end{array}$ & $\begin{array}{l}132 \\
(51.2 \%)\end{array}$ & $\begin{array}{l}32 \\
(12.4 \%)\end{array}$ & $\begin{array}{l}3.65 \\
(0.85)\end{array}$ \\
\hline 5 & $\begin{array}{l}\text { If I could choose, I would prefer teaching English } \\
\text { alone }\end{array}$ & $\begin{array}{l}5 \\
(1.9 \%)\end{array}$ & $\begin{array}{l}38 \\
(14.7 \%)\end{array}$ & $\begin{array}{l}99 \\
(38.4 \%)\end{array}$ & $\begin{array}{l}85 \\
(32.9 \%)\end{array}$ & $\begin{array}{l}31 \\
(12.0 \%)\end{array}$ & $\begin{array}{l}3.38 \\
(0.94)\end{array}$ \\
\hline
\end{tabular}

TABLE 2:

MAIN THEMES FROM THE INTERVIEW ANALYSIS

\begin{tabular}{|l|l|}
\hline & Theme \\
\hline 1 & NESTs must be qualified teachers from the perspective of fairness. \\
\hline 2 & NESTs must be qualified teachers from the perspective of team teaching effect. \\
\hline 3 & NESTs-NNESTs team teaching is beneficial to students because both kinds of teachers can complement each other. \\
\hline 4 & $\begin{array}{l}\text { NESTs-NNESTs team teaching is beneficial to students because it creates positive learning atmosphere and environment for students and } \\
\text { brings students a new learning experience. }\end{array}$ \\
\hline 5 & NESTs-NNESTs team teaching is beneficial to teachers' professional development. \\
\hline 6 & Concern about NESTs' dominance and NNESTs' marginalization in team taught classes. \\
\hline 7 & Concern about communication problems with NESTs in team teaching partnerships. \\
\hline 8 & Teaching alone would be a more 'effective' way of teaching English than team teaching with NESTs. \\
\hline
\end{tabular}




\section{REFERENCES}

[1] Achinstein, B. (2002). Conflict amid community: The micropolitics of teacher collaboration. Teacher College Record, 104 (3), 421-455.

[2] Arkoudis, S. (2003). Teaching English as a second language in science classes: Incommensurate epistemologies? Language and Education, 17, 161-173.

[3] Arkoudis, S. (2006). Negotiating the rough ground between ESL and mainstream teachers. International Journal of Bilingual Education and Bilingualism, 9, 415-433.

[4] Beijaard, D., Meijer, P. C., \& Verloop, N. (2004). Reconsidering research on teachers' professional identity. Teaching and Teacher Education, 20, 107-128.

[5] Booth, R., Dixon-Brown, M., \& Kohut, G. (2003). Shared teaching models for business communication in a research environment. Business Communication Quarterly, 66 (3), 23-38.

[6] Borko, H. (2004). Professional development and teacher learning: Mapping the terrain. Educational Researcher, 33 (8), 3-15.

[7] Boyle, J. (1997). Native-speaker teachers of English in Hong Kong. Language and Education, 11(3), 163-181.

[8] Browne, C. M., \& Wada, M. (1998). Current issues in high school English teaching in Japan: An exploratory survey. Language, Culture and Curriculum, 11(1), 97-112.

[9] Buckley, F. J. (2000). Team Teaching: What, Why, and How. Thousand Oaks, CA: Sage Publications Inc.

[10] Carless, D. (2002). Conflict or collaboration: Native and non-native speakers team teaching in schools in South Korea, Japan, and Hong Kong. Paper presented at the 7th ESEA conference, Baptist University.

[11] Carless, D. (2004). JET and EPIK: Comparative perspectives. Paper presented at the KOTESOL, Busan, South Korea.

[12] Carless, D. (2006). Collaborative EFL teaching in primary schools. ELT Journal, 60(4), 328-335.

[13] Carless, D. \& Walker, E. (2006). Effective team teaching between local and native-speaking English teachers. Language and Education, 20 (6), 463-477.

[14] Chai, C. S., \& Tan, S. C. (2009). Professional development of teachers for computer-supported collaborative learning: A knowledge-building approach. Teachers College Record, 111, 1296-1327.

[15] Chan, C. K., \& Pang, M. F. (2006). Teacher collaboration in learning communities. Teaching Education, 17 (1), 1-5.

[16] Clement, M. \& Vandenberghe, R. (2000). Teachers' professional development: A solitary or collegial (ad)venture? Teaching and Teacher Education, 16, 81-101.

[17] Clouder, L., Dalley, J., Hargreaves, J., Parkes, S., Sellars, J., \& Tom. J. (2006). Electronic [re]constitution of groups: Group dynamics from face-to-face to an online setting. Computer-Supported Collaborative Learning, 1, 467-480.

[18] Cochran-Smith, M (2004). Walking the road: Race, diversity, and social justice in teacher education. New York: Teachers College Press.

[19] Cohen, E. (1994). Restructuring the classroom: Conditions for productive small groups. Review of Educational Researcher, 32 (1), 9-13.

[20] Conn, Cynthia. E. (2010). Learning the hard way (but still learning): Using team teaching as a vehicle for pedagogical change. Business Communication Quarterly, 73(1), 87-91.

[21] Cook, L., \& Friend, M. (1995). Co-teaching: Guidelines for creating effective practices. Focus on Exceptional Children, 28 (3), $1-16$.

[22] Cramer, E., Liston, A., Nevin, A., \& Thousand, J. (2010). Co-teaching in urban secondary school districts to meet the needs of all teachers and learners: Implications for teacher education reform. International Journal of Whole Schooling, 6 (2), 59-76.

[23] Crawford, L., Schmeister, M. \& Biggs, A. (2008). Impact of intensive professional development on teachers' use of sheltered instruction with students who are English language learners. Journal of In-service Education, 34 (3), 327-342.

[24] Creese, A. (2005). Teacher collaboration and talk in multilingual classrooms. Clevedon, England: Multilingual Matters.

[25] Creese, A. (2006). Supporting talk? Partnership teachers in classroom interaction. International Journal of Bilingual Education and Bilingualism, 9, 434-453.

[26] Darling-Hammond, L. (2006). Constructing $21^{\text {st }}$ century teacher education. Journal of Teacher Education, 19, 499-514.

[27] Darling-Hammond, L., \& Richardson, N. (2009). Teacher learning: What matters? Educational Leadership, 66 (5), $46-53$.

[28] Davison, C. (2006). Collaboration between ESL and content teachers: How do we know when we are doing it right? International Journal of Bilingual Education and Bilingualism, 9, 454-475.

[29] DelliCarpini, M. (2008). Teacher collaboration for ESL/EFL academic success. Internet TESL Journal, 14 (8). Retrieved from http://iteslj.org/Techniques/DelliCarpini-TeacherCollaboration.html

[30] Desimone, L. M. (2009). Improving impact studies of teachers' professional development: toward better conceptualizations and measures. Educational Research, 38 (3), 181-199.

[31] Dillenbough, P. (2002). Over-scripting CSCL: The tasks of blending collaborative learning with instructional design. In P. Kirschner (Ed.), Three worlds of CSCL. Can we support CSCL (pp.61-92). Heerlen: Open University.

[32] Dove, M., \& Honigsfeld, A. (2010). ESL coteaching and collaboration: Opportunities to develop teacher leadership and enhance student learning. TESOL Journal, 1 (1), 3-22.

[33] Friend, M., \& Cook, L. (2010). Interactions: collaboration skills for school professionals. Columbus, OH: Merrill.

[34] Friend, M., Cook, L., Hurley-Chamberlain, D., \& Shamberger, C. (2010). Co-teaching: An illustration of the complexity of collaboration in special education. Journal of Educational and Psychological Consultation, 20, 9-27.

[35] Fujimoto-Adamson, N. (2010). Voices from team-teaching classrooms: A case study in junior high schools in Japan. Business Communication Quarterly, 73 (1), 200-205.

[36] Gardiner, W., \& Robinson, K. (2009). Paired field placements: a means for collaboration. The NEW Educator, 5, 81-94.

[37] Gardner, S. (2006). Centre-stage in the instructional register: Partnership talk in primary EAL. International Journal of Bilingual Education and Bilingualism, 9, 476-494.

[38] Gaytan, J. (2010). Instructional strategies to accommodate a team-teaching approach. Business Communication Quarterly, 73 (1), 82-87. 
[39] Goel, V. (1992). Comparison of well-structured \& ill-structured task environments and problem spaces. In J. Kruschke (Ed.), Proceedings of the Fourteenth Annual Conference of the Cognitive Science Society (pp.844-849). Hillsdale, NJ: Erlbaum.

[40] Guiney, E. (2001). Coaching isn't just for athletes: The role of teacher leaders. Phi Delta Kaappan, 82, 740-743.

[41] Hang, Q., \& Rabren, K. (2009). An examination of co-teaching: Perspectives and efficacy indicators. Remedial and Special Education, 30 (5), 259-268.

[42] Jonassen, D. H. (2000). Toward a design theory of problem solving. Educational Technology Research and Development, 48 (4), 63-85.

[43] Kumabe, N. (1996). What the introduction of ALTs has brought. Modern English Teaching, 33(6): 13.

[44] Laurillard, D. (2009). The pedagogical challenges to collaborative technologies. International Journal of Computer-Supported Collaborative Learning, 1, 5-20.

[45] LeCornu, R. (2005). Peer mentoring: Engaging preservice teachers in mentoring one another. Mentoring \& Tutoring: Partnership in Learning, 13 (3), 355-366.

[46] Lee, I. (2011). Teachers as presenters at continuing professional development seminars in the English-as-a-foreign-language context: 'I find it more convincing'. Australian Journal of Teacher Education, 36 (2), 30-42.

[47] Lockhorst, D., Admiraal, W., \& Pilot, A. (2010). CSCL in teacher training: What learning tasks lead to collaboration? Technology Pedagogy and Education, 19 (1), 63-78.

[48] Lung, J. (1999). A Local Teacher Views the Native English Teacher Scheme in Hong Kong. TESOL Matters, June/July: 8.

[49] Mahoney, S. (2004). Role controversy among team teachers in the JET Programme. JALT Journal, 26(2), 223-243.

[50] Marilyn, A. D. (2010). Team teaching: Part 1. Business Communication Quarterly, 73 (1), 80-82.

[51] McConnell, D. L. (2000). Importing diversity: inside Japan's JET Program. London: University of California Press.

[52] McHatton, P. A. \& Daniel, P. L. (2008). Co-teaching at the pre-service level: Special education majors collaboration with English education majors. Teacher Education and Special Education, 31 (2), 118-131.

[53] Medgyes, P. (1992). 'Native or non-native: Who's worth more?'. ELT Journal, 46(4), 340-349.

[54] Niederhauser, J. (1995). South Korea's globalization program: What it means for native English speakers. TESOL Journal, 5(1), 4-5.

[55] Pawan, F., \& Ortloff, J. (2011). Sustaining collaboration: English-as-a-second-language, and content-area teachers. Teaching and Teacher Education, 27 (2), 463-471.

[56] Pedder, D., \& MacBeath, J. (2008). Organizational learning approaches to school leadership and management: Teachers' values and perceptions of practice. School Effectiveness and School Improvement, 19, 207-224.

[57] Reiko, K. \& Lee, C. (2001). A tandem of native and non-native teachers: Voices from Japanese and American teachers in the EFL classroom in Japan. Paper presented at the Annual International Conference on Language Teacher Education. Minneapolis, MN.

[58] Richardson, V. (1996). The role of attitudes and beliefs in learning to teach. In J. Sikula (Ed.), Handbook of research on teacher education (pp. 102-119). New York: Macmillan.

[59] Servage, L. (2008). Critical and transformative practices in professional learning communities. Teacher Education Quarterly, 35 (1), 63-77.

[60] Tajino, A., \& Tajino, Y. (2000). Native and non-native: What can they offer? ELT Journal, 54(1), 3-11.

[61] Timostsuk, I., \& Ugaste, A. (2010). Student teachers' professional identity. Teaching and Teacher Education, 26, 1563-1570.

[62] Wayne, A. J., Yoon, K. S., Zhu, P., Cronen, S. \& Garet, M. S. (2008). Experimenting with teacher professional development: Motives and methods. Educational Researcher, 37 (8), 469-479.

[63] York-Barr, J., Ghere, G., \& Sommerness, J. (2007). Collaborative teaching to increase ELL student learning: A three-year urban elementary case study. Journal of Education for Students Placed at Risk, 12 (3), 301-335.

Li-Yi Wang obtained his Master of Science in TESOL at University of Stirling, United Kingdom and Ph.D. degree at Deakin University, Australia. He is currently a Research Fellow in the Office of Education Research, National Institute of Education, Singapore. His research interests are professional identity of English teachers and English language teacher education. 